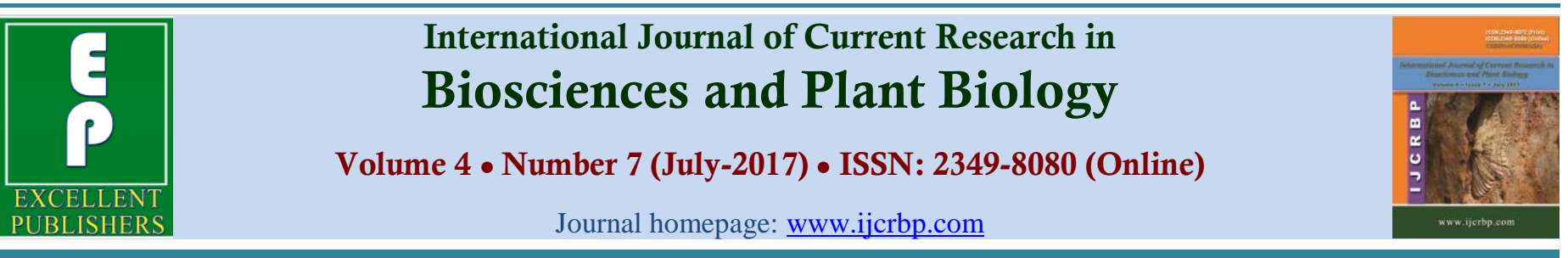

\title{
In Vitro and Computational Assessment of Genotoxic Potential of Active Constituents Present in Three Medicinally Important Plant Extracts
}

\author{
Sudipta Joardar ${ }^{1}{ }^{\$}$, Sharmila Ghosh $^{1 \$}$, Sohini Gupta $^{2}$ and Sayak Ganguli ${ }^{3}$ \\ ${ }^{I}$ The Biome, 10B Girish Avenue, P.O. Baghbazar, Kolkata - 700 003, West Bengal, India \\ ${ }^{2}$ Department of Botany, Barasat Government College, Barasat, North 24 Parganas, Kolkata - 700 124, West Bengal, India \\ ${ }^{3}$ Theoretical and Computational Biology Division, AIIST, Palta - 743 122, West Bengal, India
}

*Corresponding author; ${ }^{\$}$ Equal contribution.

\begin{abstract}
In order to investigate the cytological effects of methanolic extracts of three commonly known medicinal plants: Catharanthus roseus (L.) G.Don, Phyllanthus reticulatus Poir. and Bacopa monnieri(L.)Pennell was evaluated using Allium cepa $\mathrm{L}$. assay followed by computational analysis through molecular docking. The study was extended to elucidate the interactions of the major active principles of the extracts with possible cellular targets such as histones; in cases where chromatin disruption was exhibited as direct effect of treatment. Wet lab experiments were performed prior to the computational analysis. Comparative modelling using modeller v.9.18 was used to obtain the 3D structures of histones and protein ligand interactions were studied using PATCHDOCK server and validated using AUTODOCK. Small molecule structures were obtained from PUBCHEM and were converted to 3D using OPENBABEL. The docked complexes were then subjected to analysis using PDBSUM to obtain the specific interaction sites. Meta-analysis was performed using VENNY v.2.0. Results indicate that most of the crude extracts exerted mitotic arrest at prophase while some chromatoclasic and mitoclasic aberrations were noted. Computational studies revealed that most of the active constituents had unique binding sites with histones. This observation indicates that histone-small molecule interactions might play a role in formation of aberrant cytological phenotypes.
\end{abstract}

\section{Article Info}

Accepted: 23 June 2017

Available Online: 06 July 2017

Keywords

Chromatoclasic aberration

Mitoclasic aberration

Molecular docking

\section{Introduction}

From medicines to natural products, impact of medicinal plants is not alien to us. Catharanthus comprise 130 terpenoid indole alkaloids. Vinblastine is one the chief components of Catharanthus extract which is reported to be useful as an anticancer drug (van Der Heijden et al., 2004). Two dimeric indole alkaloids viz., vinblastine and vincristine are obtained from Catharanthus roseus.
Their monomeric precursor molecules are vindoline and catharanthine. Certain evidences are available now about the action of vinblastine and vinblastine in mitotic spindle poisons (Sertel et al., 2011). On the contrary use of microtubule inhibitors is broadly implemented in chemotherapy, but mechanisms that link microtubule disarray to destructive or protective cellular responses are hardly clear till now. Substances like Vb, Vc, taxol, and derivative like doxorubicin reported to have 
microtubule disruption (Stone and Chambers, 2000). Traditionally plants are commonly regarded as the first component for preparing medicines to deal with. New drugs are synthesized in their tissues along with plant specific special structures.

Taxol, camptothecin, vincristine $(\mathrm{Vc}), \mathrm{Vb}$ are some of them. Vinca alkaloids have autophagic effect (Nevalainen, 1975). Advanced bioinformatics softwares like PASS (Prediction of Activity Spectra for Substances) are used in recent times to predict the targets of these anticancer small molecules with more accuracy (Hashemi et al., 2012).

Different species of Phyllanthus comprise alkaloids like phyllanthine, quercetin, securinine, etc. (Calixto et al., 1998). In addition 1-3 g powder of Bacopa monnieri (L.) Pennell. $(\mathrm{Bm})$ are used to treat several skin diseases (API, 2009). Bacopa monnieri is a source of bacosides responsible for the memory enhancing property that has resulted in extensive use of this plant in several commercial preparations and placed the plant in high demand (Rahman et al., 2002). Docking of Bacoside-A with proteins reveal the active binding sites along with interaction of drugs (Chandrasekar et al., 2013).

Plants are not only unprecedented sources of ample drugs but also drug precursors in pharmaceutical chemistry. Production of some biologically active constituents like vinblastine $(\mathrm{Vb})$, quercetin $(\mathrm{Qt})$, and bacopasaponin $\mathrm{C}(\mathrm{BaC})$ in limited amount in plant tissues is undoubtedly a challenge especially when it is bridged with drug discovery (Leonard et al., 2009). Intercalation along with small-molecule DNA interaction is always a significant aspect of research for decades. Regulation of biological functions is dependent on binding of these small molecules with proteins (Snyder et al., 2005).

Intercalation, groove binding, noncovalent interactions between biological molecules are potential factors to investigate the mechanism of genotoxicity though these factors were not regarded so significant earlier. Requirement of such method leads to the generation of molecular docking and simulation which encompasses the determination of the nature of interactions between molecules such as hydrogen bonding, electrostatic interaction or anything else (Snyder et al., 2013).

These plants are miracle factories of magical compounds. Use of such chemicals and their mode of action along with effects have been studied for long time. Chromosomal damage is one of the aspects of such effects. Alkaloids and flavonoids have been reported to have maximum effects on cells along with chromosomes and histones in comparison to other compounds (Gupta et al., 2013). Plant extracts have been used for a long time and statistically it has been reported from various research works that these compounds are effective against sleeping sickness, wounds, diarrhoea and stomach infections including reproductive problems, circulatory and parasitic infections (Abdel-Magied et al., 2001; Adewunmi et al., 2001; Ajaiyeoba et al., 2003; Amegnona et al., 2003; Chattopadhyay, 2003; Ettarh and Emeka., 2004; Vandna et al., 2005; Chah et al., 2006; Rakuambo et al., 2006; Obi et al., 2006).

Studies obtained from Allium, Ames, and MTT tests reveal that aqueous extract of Limonium globuliferum Kuntze. show mutagenic and genotoxic effects. Further analysis of Allium test concludes that aqueous extracts of this species comprise toxicity in a dose-dependent manner and induce chromosomal anomalies which are undoubtedly related to formed defects in the spindle fibres (Erena and Özatab, 2014). According to chromosome aberration assay of Allium cepa Linn. treated with aqueous extract of Azadirachta indica A.Juss. there is a suppression of mitotic index showing various kinds of aberrations like micronucleus, anaphase bridges, laggards and stickiness, polyploidy and disturbed anaphase (Chattopadhyay, 2003).

Qt is generally found in products comprising good impact on health. Osteoporosis, certain forms of cancer, pulmonary and cardiovascular diseases are treated with Qt containing substances. The property of eradicating substances like peroxynitrite and the hydroxyl radicals from the body performed by Qt leads these helpful benefits to our health (Boots et al., 2008). Effects of these molecules are now subjected to computational analysis through molecular docking like use of AUTODOCK in order to investigate their anticancer and other properties with accuracy at molecular level. This also helps to identify the nature of formed complexes with receptor proteins present in cell cycle and other biological processes (Phosrithong, 2010).

Studies obtained from in-silico molecular docking contributes to determine potential biomolecular targets such as phytochemical components of antitrypanosomal plants. Besides it also helps to determine structural manifolds of phytochemicals. Synthetic modification of 
biologically active compounds have become possible because of the availability of structural motifs (Setzer and Ogungbe, 2012). Pharmacoinformatics greatly contribute to the field of drug discovery, drug design along with verification and advancement of drug protein interaction. Identification of potential drug targets is also another significant aspect of computational analysis (Chen et al., 2009).

Identification of binding site of a ligand with its affinity in a target site of a macromolecule like protein has become possible because of molecular docking. It is based on the 3D structure of the target or ligand. In molecular docking which is ligand based, target site of a known inhibitor is used in order to get the structural information in as detail as possible (Yuriev and Ramsland, 2013).

Extracts of medicinal plants may be used internally and externally. But to confirm its impacts we need to perform quantitative and qualitative analysis with clinical trials. As part of an ongoing study on genetic safety evaluation of extracts commonly used medicinal plants. This study was conducted to investigate the possible genotoxic effects of extracts of Catharanthus roseus (L.) G.Don. (Cr), Phyllanthus reticulatus Poir. (Pr) and Bacopa monnieri (L.) Pennell. (Bm) using widely accepted Allium test. Although more emphasis is given to the computational and meta-analysis in order to determine binding affinity along with binding site of the biologically active compounds with possible cellular targets like histones.

\section{Materials and methods}

\section{Medicinal plants used}

The medicinal plants used in this study are Catharanthus roseus (L.). G. Don, Phyllanthus reticulatus Poir. and Bacopa monnieri (L.) Pennell. They are collected from the medicinal plant garden in the campus.

\section{Preparation of extract}

Collected samples were cleansed, chopped, air dried at room temperature and finally grinded into powder. From each plant sample, $100 \mathrm{~g}$ powder was macerated with ethanol (1:5) in a sealed container for 5 days at room temperature with occasional shaking. Extract of each sample was filtered separately through
Whatman No.1 filter paper and was evaporated to dryness under vacuum below $50^{\circ} \mathrm{C}$ to get about $3 \mathrm{~g}$ blackish green colored extract. The leaf extract thus prepared was kept at $4^{\circ} \mathrm{C}$ for future use.

\section{Methods}

Methods followed while conducting this experiment were divided in two categories viz., Wet Laboratory Works and Dry Laboratory Works.

\section{Wet laboratory work}

In order to grow roots hydroponic setups of onion bulbs were made. After keeping it for two days root of average size of $1 \mathrm{~cm}$ were grown and then isolated from the onion. Then root tips suitable for the experiment were removed. A blank control i.e., water, a negative control i.e., methanol and two experimental setups were made. Root tips were kept in each set up for 2 and $4 \mathrm{hrs}$. A.N. Sharma protocols were followed to prepare slides.

\section{Dry laboratory work}

At the advent of our dry lab work three dimensional structures of plant histones i.e. $\mathrm{H} 1 \mathrm{H}, \mathrm{H} 2 \mathrm{AH} 1, \mathrm{H} 2 \mathrm{AH} 2$, $\mathrm{H} 2 \mathrm{AH} 3, \mathrm{H} 2 \mathrm{BH}, \mathrm{H} 3 \mathrm{H}, \mathrm{H} 3 \mathrm{H} 2, \mathrm{H} 3 \mathrm{H} 3, \mathrm{H} 4 \mathrm{H}, \mathrm{H} 4 \mathrm{H} 2$ and alkaloids given in Table 1 were determined with the help of NCBI-PUBCHEM and Openbabel software. After that all the possible combinations taking one histone and one alkaloid at a time were made in 'pdb' file format. Each file was sent to "PATCHDOCK" server in order to get atomic contact energy values for each combination.

Next each file was sent to "PDBSUM" of European Bioinformatics Institute (EBI). Data obtained from EBIPDBSUM containing number of hydrogen bonds and non-contact interactions between each histone and alkaloid was obtained. Simultaneously "UCSFCHIMERA" and 'ICM BROWSER' were used to get three dimensional model of each combination. Atomic contact energy values of all alkaloids for each plant are plotted in line graphs. Eventually "VENNY" software was used to do a comparative study among different alkaloids and their interactions mathematically.

\section{Results and discussion}

As the entire experiment was performed under dry and wet lab protocols the outcomes are separately mentioned below with Tables 1-5 and Figs. 1-6. 
Table 1. Biologically active constituents present in the plants used in the experiment.

\begin{tabular}{ll}
\hline Plant & Active constituents \\
\hline Catharanthus roseus (L.) G. Don & Vinblastine, vincristine, etc. \\
Phyllanthus reticulatus Poir. & Phyllanthine, securinine, quercetin, etc. \\
Bacopa monnieri (L.)Pennell & Bacoside A, bacopaside 1, bacopasaponin C, etc. \\
\hline
\end{tabular}

Table 2. Values of average mitotic indices (M.I.) in different experimental setups with respect to different time duration.

\begin{tabular}{lll}
\hline & M.I 2 hrs. & M.I 4 hrs. \\
\hline Water (+ve control) & 7.304 & 5.437 \\
Methanol (-Ve control) & 10.20 & 13.927 \\
Cr & 22.801 & 24.13 \\
Pr & 6.146 & 7.948 \\
Bm & 10.61 & 11.93 \\
Water (+ve control) - prophase & 6.83 & 5.19 \\
Methanol (-ve control) - prophase & 12.78 & 13.21 \\
Cr- prophase & 22.52 & 22.89 \\
Pr- prophase & 5.28 & 6.25 \\
Bm- prophase & 9.80 & 11.66 \\
Water (+ve control) - metaphase & 0.23 & 0.22 \\
Methanol (-ve control) - metaphase & 0.61 & 0.64 \\
Cr- metaphase & 0.24 & 2.00 \\
Pr - metaphase & 0.73 & 0.00 \\
Bm- metaphase & 1.19 & 0.23 \\
Water (+ve control) - anaphase & 0.00 & 0.00 \\
Methanol (-ve control) - anaphase & 0.39 & 0.27 \\
Cr - anaphase & 0.06 & 0.40 \\
Pr - anaphase & 1.34 & 0.00 \\
Bm - anaphase & 0.65 & 0.00 \\
Water (+ve control) - telophase & 0.00 & 0.00 \\
Methanol (-ve control) - telophase & 0.17 & 0.32 \\
Cr- telophase & 0.06 & 0.00 \\
Pr- telophase & 0.13 & 0.00 \\
Bm - telophase & 0.24 & 0.00 \\
\hline
\end{tabular}

Table 3. Aberrations found after treated with methanol extract of plants used in the experiment.

\begin{tabular}{|c|c|c|c|c|c|}
\hline 2 Hrs & +ve control & -ve control & Pr & $\mathrm{Cr}$ & $\mathbf{B m}$ \\
\hline Normal cells & 62 & 252 & 112 & 385 & 117 \\
\hline Aberrations & 0 & 0 & 7 & 1 & 3 \\
\hline $\begin{array}{l}\text { Mitoclasic } \\
\text { aberrations }\end{array}$ & 0 & 0 & $\begin{array}{l}5 \text { (Clump 3) (Fragmentation } \\
\text { 2) }\end{array}$ & 0 & $\begin{array}{l}2 \text { ( Clump 1) } \\
\text { (Fragmentation } 1 \text { ) }\end{array}$ \\
\hline $\begin{array}{l}\text { Cromatoclasic } \\
\text { aberrations }\end{array}$ & 0 & 0 & 2 (Anaphase bridge 2 ) & $\begin{array}{l}1 \text { (Anaphase } \\
\text { bridge 1) }\end{array}$ & 1 (Sticky bridge 1) \\
\hline 4 Hrs & +ve Control & -ve Control & Pr & $\mathrm{Cr}$ & $\mathbf{B m}$ \\
\hline Normal cells & 51 & 410 & 168 & 190 & 210 \\
\hline Aberrations & 0 & 1 & 9 & 0 & 1 \\
\hline $\begin{array}{l}\text { Mitoclasic } \\
\text { aberrations }\end{array}$ & 0 & 0 & $\begin{array}{l}7 \text { ( Clump 4) } \\
\text { (Fragmentation 3) }\end{array}$ & 0 & 0 \\
\hline $\begin{array}{l}\text { Chromatoclasic } \\
\text { aberrations }\end{array}$ & 0 & 0 & 2 (Anaphase bridge 2 ) & 0 & 1(Sticky bridge) \\
\hline
\end{tabular}

\section{Study of mitotic index}

Mitotic index is defined as the ratio between the numbers of cells in a population undergoing mitosis to the number of cells not undergoing mitosis. The mitotic index is simply a measurement to determine the percentage of cells undergoing mitosis. Mitosis is the division of somatic cells when genetic information from one single cell is equally dispersed into two daughter cells. Durations of the cell cycle and mitosis vary in different cell types. The formula generally used is

$$
M . I=(P+M+A+T) * \frac{100}{N}
$$


Where, $(\mathrm{P}+\mathrm{M}+\mathrm{A}+\mathrm{T})$ are the sum of all cells in phase as prophase, metaphase, anaphase and telophase, respectively; $\mathrm{N}$ - total number of cells.

\section{Dry lab outcome}

Computational studies through molecular docking provide atomic contact energy values of docked complexes.

Table 1 shows the biologically active constituents present in the plants used in the experiment. The potential genotoxic effects of the extract of Catharanthus roseus (L.). G. Don., Phyllanthus reticulatus Poir. and Bacopa monnieri (L.) Pennell. on Allium cepa Linn. cells were evaluated. These plants are selected for the experiment as they possess huge importance in pharmaceutical industry. Mitotic index obtained from the treatment of Catharanthus roseus (L.). G. Don (2 hrs) extract and Phyllanthus reticulatus
Poir. (2 hrs) extract is significantly different from mitotic index of positive control (Table 2; Fig. 1). There is a recognizable increase in the mitotic index of prophase in the treatment of Catharanthus roseus (L.). G. Don in comparison to positive control. Same method was applied and compared with negative control using methanol but no significant result was obtained. Though increase of mitotic arrest in prophase in case of Bacopa also observed but the number is hardly significant. Thus we can safely conclude that constituents of the crude extract are inducing mitotic arrest following prophase. On the contrary, treatment of $4 \mathrm{hrs}$ Phyllanthus extract on Allium cells increased the mitotic index of prophase though the rate is not so significant in comparison to Catharanthus. Some chromosomal aberrations were found in all cases (Table 3). Histones are the chief protein component of chromatin, acting as spools around which DNA winds. So analysis through bioinformatics was done in order to study the putative interactions between histones and active constituents of the crude extracts.

Table 4. Comparative studies between different parameters with respect to each plant.

\begin{tabular}{llllll}
\hline Plant & Histone & $\begin{array}{l}\text { Average A.C.E } \\
\text { value }\end{array}$ & $\begin{array}{l}\text { Average no. of } \mathbf{H} \\
\text { bond(s) }\end{array}$ & $\begin{array}{l}\text { Average no. of non- } \\
\text { bonded contact(s) }\end{array}$ & $\begin{array}{l}\text { A.C.E value per H } \\
\text { bond }\end{array}$ \\
\hline $\mathrm{Cr}$ & H1H & -610.29 & 5 & 205.5 & -122.05 \\
& H2AH1 & -559.98 & 0 & 200.5 & Undefined \\
& H2AH2 & -535.90 & 1 & 109 & -535.90 \\
& H2AH3 & -447.82 & 0.5 & 140 & -895.64 \\
& H3H & -517.51 & 0.5 & 97 & -1035.02 \\
& H3H2 & -517.51 & 0.5 & 97 & -1035.02 \\
& H3H3 & -457.88 & 0 & 71.5 & Undefined \\
& H2BH & -500.80 & 3 & 128 & -166.94 \\
& H4H & -571.20 & 0.5 & 143 & -1142.40 \\
& H4H2 & -571.20 & 0.5 & 143 & -1142.40 \\
\hline Pr & H1H & -279.62 & 4.33 & 102 & -64.58 \\
& H2AH1 & -228.05 & 1.33 & 37.33 & -171.47 \\
& H2AH2 & -233.15 & 0.33 & 39.33 & -706.52 \\
& H2AH3 & -219.02 & 1.67 & 37.67 & -131.15 \\
& H3H & -276.25 & 0 & 133 & Undefined \\
& H3H2 & -276.25 & 0 & 99.67 & Undefined \\
& H3H3 & -229.08 & 0.67 & 87.67 & -341.91 \\
& H2BH & -207.00 & 0 & 27 & Undefined \\
& H4H & -205.69 & 0 & 65.67 & Undefined \\
& H4H2 & -205.69 & 2 & 84.33 & -102.85 \\
\hline Bm & H1H & -534.04 & 2.33 & 180.67 & -64.58 \\
& H2AH1 & -461.37 & 1 & 135.33 & -171.47 \\
& H2AH2 & -506.65 & 0.33 & 99.33 & -706.52 \\
& H2AH3 & -443.89 & 3 & 133.33 & -131.15 \\
H3H & -448.17 & 0.33 & 101.33 & -136.00 \\
H3H2 & -404.39 & 0.33 & 120.33 & -123.00 \\
H3H3 & -516.52 & 1.33 & 92.67 & -341.91 \\
H2BH & -485.42 & 1.33 & 59.33 & -364.98 \\
H4H & -546.15 & 0.33 & 123 & -1655.00 \\
H4H2 & -546.15 & 0.66 & 128.33 & -102.85 \\
\hline
\end{tabular}


Table 5. List of absence of hydrogen bonds between active constituents and histones.

\begin{tabular}{ll}
\hline Active constituent & Histones \\
\hline Vinblastine & $\mathrm{H} 2 \mathrm{AH} 1, \mathrm{H} 3 \mathrm{H} 3, \mathrm{H} 2 \mathrm{BH}$. \\
Vincristine & $\mathrm{H} 2 \mathrm{AH} 1, \mathrm{H} 2 \mathrm{AH} 3, \mathrm{H} 3 \mathrm{H}, \mathrm{H} 3 \mathrm{H} 2, \mathrm{H} 3 \mathrm{H} 3, \mathrm{H} 4 \mathrm{H}, \mathrm{H} 4 \mathrm{H} 2$. \\
Phyllanthine & $\mathrm{H} 2 \mathrm{AH} 1, \mathrm{H} 2 \mathrm{AH} 3, \mathrm{H} 3 \mathrm{H}, \mathrm{H} 3 \mathrm{H} 2, \mathrm{H} 2 \mathrm{BH}, \mathrm{H} 4 \mathrm{H} 2, \mathrm{H} 4 \mathrm{H}, \mathrm{H} 3 \mathrm{H} 3$. \\
Securinine & $\mathrm{H} 2 \mathrm{AH} 2, \mathrm{H} 3 \mathrm{H}, \mathrm{H} 3 \mathrm{H} 2, \mathrm{H} 4 \mathrm{H}, \mathrm{H} 2 \mathrm{BH}$. \\
Quercetin & $\mathrm{H} 2 \mathrm{AH} 1, \mathrm{H} 2 \mathrm{AH} 2, \mathrm{H} 3 \mathrm{H}, \mathrm{H} 3 \mathrm{H} 2, \mathrm{H} 4 \mathrm{H}, \mathrm{H} 2 \mathrm{BH}$. \\
Bacoside A & $\mathrm{H} 2 \mathrm{AH} 1, \mathrm{H} 2 \mathrm{AH} 2, \mathrm{H} 4 \mathrm{H}, \mathrm{H} 4 \mathrm{H} 2$. \\
Bacopaside 1 & $\mathrm{H} 1 \mathrm{H}, \mathrm{H} 2 \mathrm{BH}, \mathrm{H} 2 \mathrm{AH} 2, \mathrm{H} 2 \mathrm{AH} 3, \mathrm{H} 3 \mathrm{H}, \mathrm{H} 3 \mathrm{H} 2, \mathrm{H} 3 \mathrm{H} 3, \mathrm{H} 4 \mathrm{H}, \mathrm{H} 4 \mathrm{H} 2$. \\
Bacopasaponin C & $\mathrm{H} 2 \mathrm{AH} 1, \mathrm{H} 2 \mathrm{AH} 3, \mathrm{H} 2 \mathrm{BH}, \mathrm{H} 3 \mathrm{H}, \mathrm{H} 3 \mathrm{H} 2, \mathrm{H} 4 \mathrm{H}, \mathrm{H} 4 \mathrm{H} 2$. \\
\hline
\end{tabular}
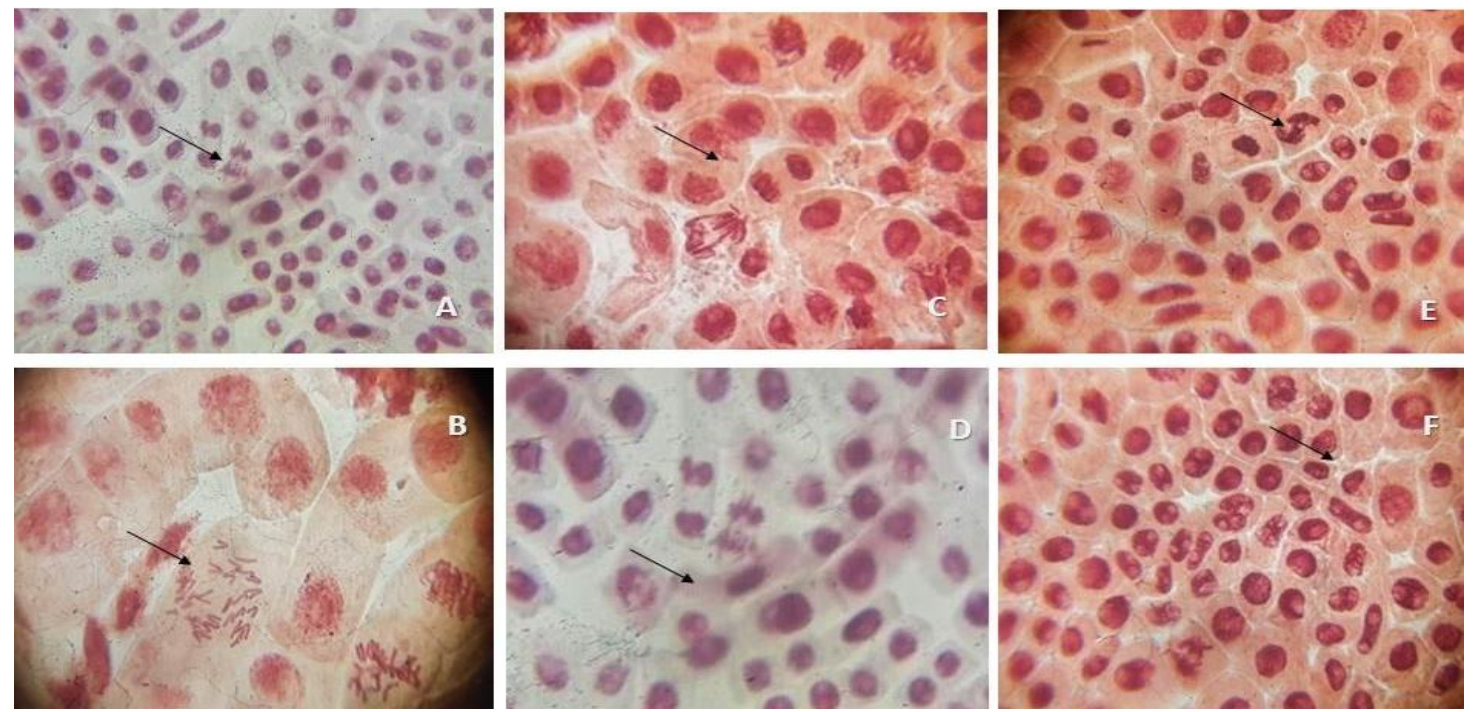

Fig. 1: A and B show mitotic cell divisions of cells of Allium cepa Linn. root tip in water and Bm extract respectively. Fig. 3: C and D shows mitotic cell divisions in methanol extract medium of Pr and methanol medium respectively. Fig. $\mathbf{E}$ and $\mathbf{F}$ shows affected mitotic cell divisions in methanol extract medium of $\mathbf{C r}$.

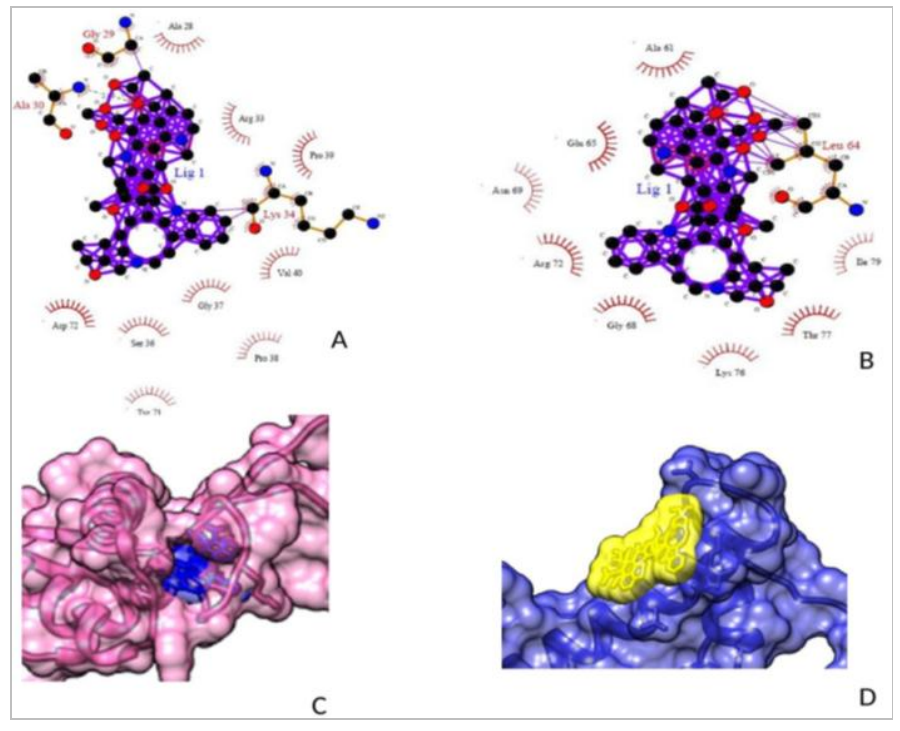

Fig. 2: $\mathbf{A}$ and $\mathbf{B}$ show interaction along with orientation of atoms between $\mathrm{H} 1 \mathrm{H}+\mathrm{Vb}$ and $\mathrm{H} 2 \mathrm{AH} 1+\mathrm{Vb}$ respectively. Fig. 2: $\mathbf{C}$ and $\mathbf{D}$ show site of attachment between $\mathrm{H} 1 \mathrm{H}+\mathrm{Vb}$ and $\mathrm{H} 2 \mathrm{AH} 1+\mathrm{Vb}$ respectively.
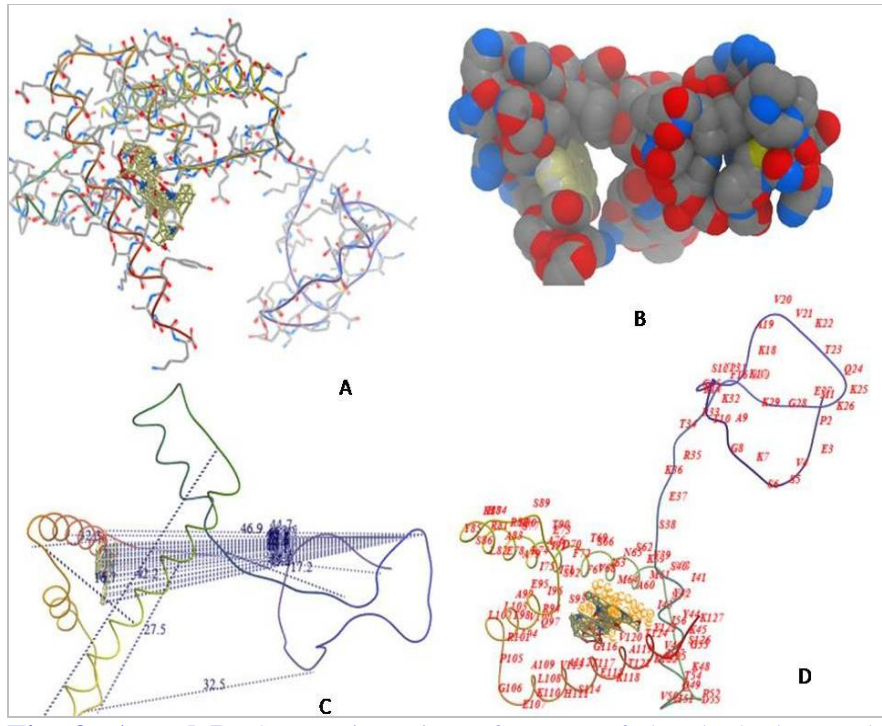

Fig. 3: A and B show orientation of atoms of the docked complex formed between $\mathrm{H} 2 \mathrm{BH}$ and $\mathrm{Vb}$. Fig. 3C shows atomic distances between different positions within the docked complex. Along with distances between different atoms of the histone and small molecule are also observed. Fig. 3D represents toggled view of atoms and residues at different levels of the docked complex. 
Table 4 shows the comparison between different parameters with respect to each plant. There is no common interaction site between $\mathrm{H} 1 \mathrm{H}+\mathrm{Vb}$ and $\mathrm{H} 1 \mathrm{H}+$ Vc. In the histone group $\mathrm{H} 2 \mathrm{AH} 1, \mathrm{H} 2 \mathrm{AH} 2$ and $\mathrm{H} 2 \mathrm{AH} 3$ vinblastine forms hydrogen bond with only $\mathrm{H} 2 \mathrm{AH} 3$. Only vincristine forms 6 hydrogen bonds with $\mathrm{H} 2 \mathrm{BH}$ whereas vincristine does not form any bonded interaction with $\mathrm{H} 2 \mathrm{BH}$. In case of interaction between $\mathrm{H} 3$ and vinblastine only $\mathrm{H} 3 \mathrm{H}$ is noticed to interact through hydrogen bond with vinblastine. Vinblastine forms only one hydrogen bond with $\mathrm{H} 4 \mathrm{H}$ and $\mathrm{H} 4 \mathrm{H} 2$ having common sites of interaction. Vincristine forms bonded contacts with only $\mathrm{H} 2 \mathrm{AH} 2$ rather than $\mathrm{H} 2 \mathrm{AH} 1$ and $\mathrm{H} 2 \mathrm{AH} 3$. Besides this there are 6 hydrogen bonded interactions in $\mathrm{BsA}+\mathrm{H} 1 \mathrm{H}$ complex. Interestingly BsA forms 9 hydrogen bonded interactions with $\mathrm{H} 2 \mathrm{AH} 3$ without forming any interaction with $\mathrm{H} 2 \mathrm{AH} 1$ and $\mathrm{H} 2 \mathrm{AH} 2$.

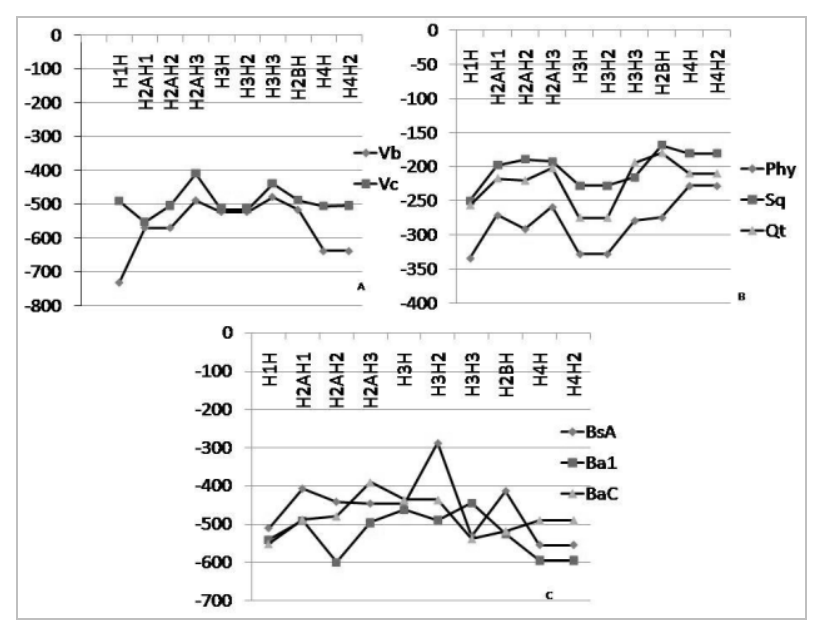

Fig. 4: shows graphical analysis of atomic contact energy values between histones and active constituents.

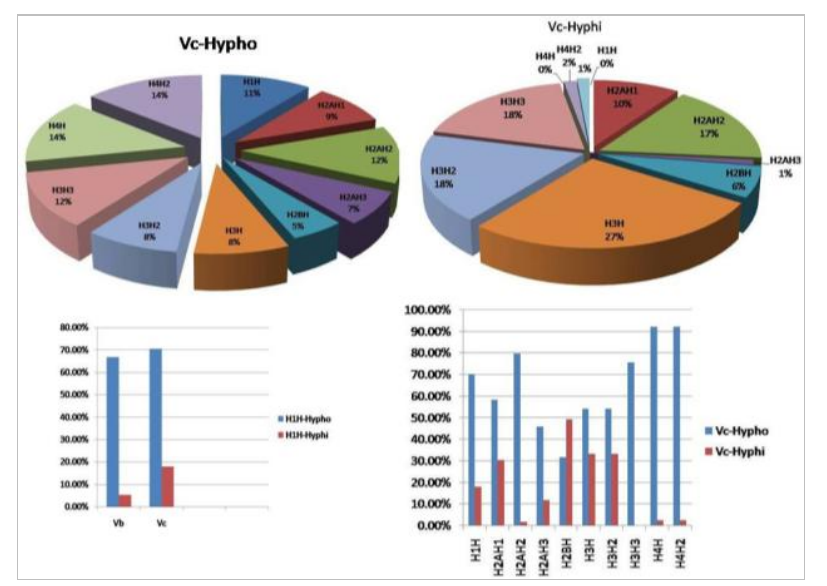

Fig. 5: Comparison among degree of hydrophobic and hydrophilic interactions between histones and small molecules like $\mathrm{Vb}$ and $\mathrm{Vc}$.
Fig. $2 \mathrm{~A}$ and $\mathrm{B}$ show interaction along with orientation of atoms between $\mathrm{H} 1 \mathrm{H}+\mathrm{Vb}$ and $\mathrm{H} 2 \mathrm{AH} 1+\mathrm{Vb}$ respectively. Fig. $2 \mathrm{C}$ and $\mathrm{D}$ show site of attachment between $\mathrm{H} 1 \mathrm{H}+\mathrm{Vb}$ and $\mathrm{H} 2 \mathrm{AH} 1+\mathrm{Vb}$ respectively. Fig. 3 $\mathrm{A}$ and $\mathrm{B}$ show orientation of atoms of the docked complex formed between $\mathrm{H} 2 \mathrm{BH}$ and $\mathrm{Vb}$. Fig. $3 \mathrm{C}$ shows atomic distances between different positions within the docked complex. Along with distances between different atoms of the histone and small molecule are also observed. Fig. 3 D represents toggled view of atoms and residues at different levels of the docked complex. Amount of common interactions between small molecules and histones are found in Fig. 4. Among BsA, $\mathrm{Ba} 1$ and $\mathrm{BaC}$, only $\mathrm{Ba} 1$ is observed not to interact with H1H. Fig. 5 provides the comparison among degree of hydrophobic and hydrophilic interactions between histones and small molecules like $\mathrm{Vb}$ and Vc. Details of non-bonded contacts are mentioned in Table 4.

$\mathrm{H} 1 \mathrm{H}$ was observed to interact with quercetin with two hydrogen bonds whereas the interactions with phyllanthine and securinine were through single hydrogen bond. Interestingly there were no common interacting residues in context of either of the three interactions. Quercetin forms only one hydrogen bond with only $\mathrm{H} 2 \mathrm{AH} 3$ without interacting with $\mathrm{H} 2 \mathrm{AH} 1$ and $\mathrm{H} 2 \mathrm{AH} 2$. As phyllanthine forms one hydrogen bond with only $\mathrm{H} 2 \mathrm{AH} 3$ rather than $\mathrm{H} 2 \mathrm{AH} 1$ and $\mathrm{H} 2 \mathrm{AH} 2$. There is no question about common sites of interactions. There are four common hydrogen bonded contacts between $\mathrm{H} 2 \mathrm{AH} 1+$ securinine and $\mathrm{H} 2 \mathrm{AH} 3+$ securinine. Securinine binds with $\mathrm{H} 3 \mathrm{H} 3$ forming 2 hydrogen bonds but having no interaction with $\mathrm{H} 3 \mathrm{H} 1$ and $\mathrm{H} 3 \mathrm{H} 2$. Consequently there is no common interaction site.

The slides prepared from wet lab work show anomalies having cell division arrested in prophase. Presence of maximum number of cells in interphase is also a part of anomaly which are treated with extracts of Catharanthus, Phyllanthus and Bacopa as well. Maximum cases hydrophobic interaction is comparatively higher between molecules and histones. Certainly the active constituents might have effect on cell division. Interactions mentioned in the above table comprise weak interaction of attachment i.e. Van Der Waal's interaction .It can be concluded from the above discussion that the abnormalities in chromosomes might be formed due to the complexes of histones and active constituent molecules having hydrogen bonds rather than interactions comprising Van Der Wal's interaction as hydrogen bonded interaction is stronger than Van 
Der Wal's interaction and thermodynamically hydrogen bond provides more stable interaction between molecules which is supported by wet lab observations (Table 5).

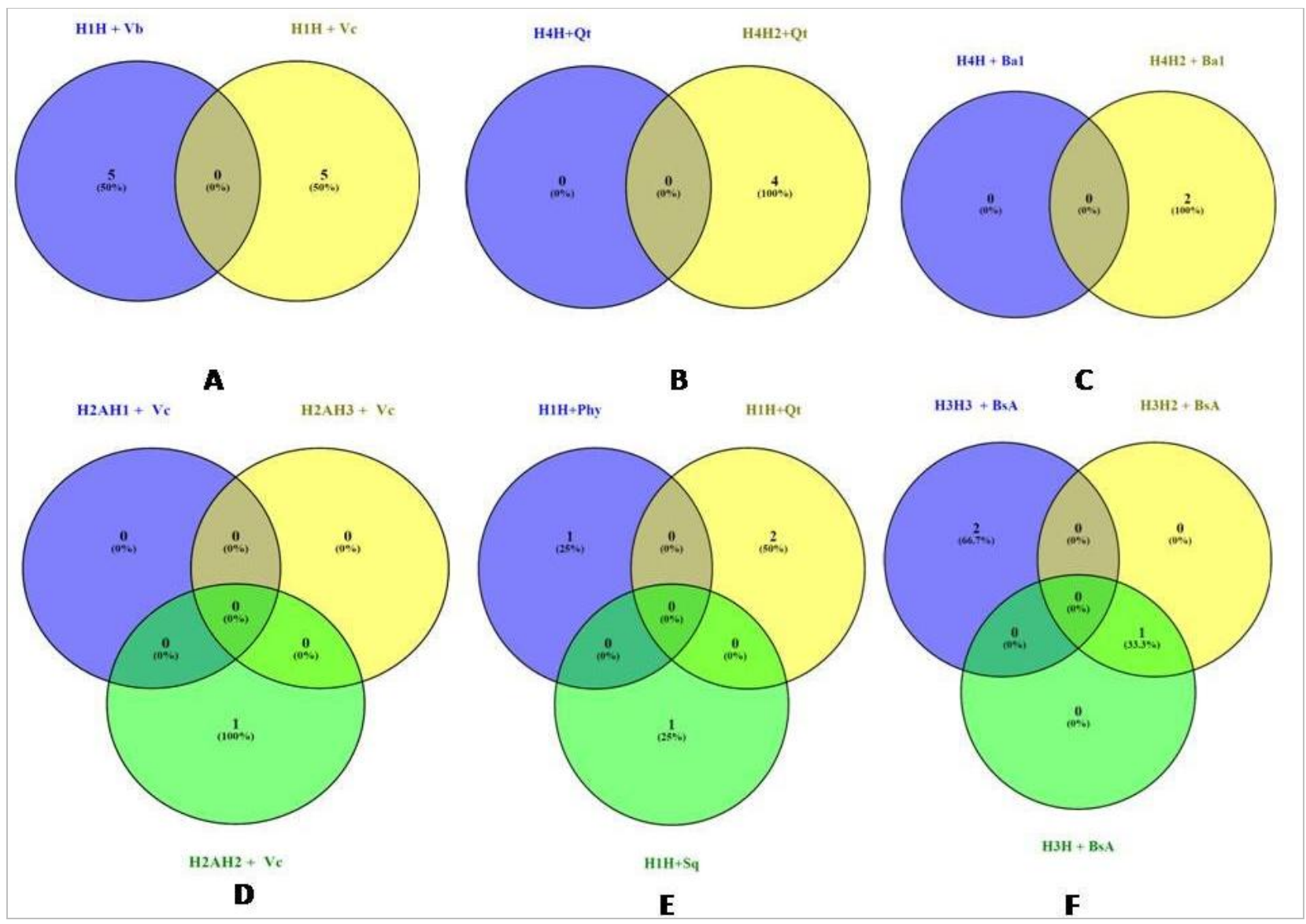

Fig. 6: Percentage of common interaction sites between small molecule and histones.

Abbreviations used in Fig. 6 are listed below:

\begin{tabular}{ll}
\hline Original name & Abbreviation \\
\hline Vinblastine & $\mathrm{Vb}$ \\
Vincristine & $\mathrm{Vc}$ \\
Quercetin & $\mathrm{Qt}$ \\
Phyllanthine & $\mathrm{Phy}$ \\
Securinine & $\mathrm{Sq}$ \\
Bacoside A & $\mathrm{BsA}$ \\
Bacopaside1 & $\mathrm{Bs} 1$ \\
BacopasaponinC & $\mathrm{BaC}$ \\
Histones & $\mathrm{H}$ \\
Catharanthus roseus (L.) G.Don & $\mathrm{Cr}$ \\
Phyllanthus reticulatus Poir & $\mathrm{Pr}$ \\
Bacopa monnieri (L.) Pennell & $\mathrm{Bm}$ \\
Hydrophobic & $\mathrm{Hypho}$ \\
Hydrophilic & $\mathrm{Hyphi}$ \\
\hline
\end{tabular}

\section{Conflict of interest statement}

Authors declare that they have no conflict of interest.

\section{Acknowledgement}

We are greatly thankful to The Biome along with Amplicon Biosciences for their sincere guidance along with the proofreading of this manuscript.

\section{References}

Abdel-Magied, E.M., Abdel-Rahman, H.A., Harraz F.M., 2001. The effect of aqueous extracts of Cynomorium coccineum and Withania somnifera on testicular development in immature Wister rats. J. Ethnopharmacol. 75, 1-4.

Adewunmi, C.O., Agbedahunsi, J.M., Adebajo. A.C., Aladesanmi, A.J., Murphy, N.,Wando, J., 2001. Ethno-veterinary medicine: Screening of Nigerian medicinal plants for trypanacidal properties. J. Ethnopharmacol. 77, 19-24.

Ajaiyeoba, E.O., Oladepo, O., Fawole, O.I., Bolaji, O.M., Akinboye, D.O.,Ogundahunsi, O.A.T., 
Falade, C.O., Gbotosho, G.O., Itiola, O.A., Happi, T.C., Ebong ,O.O., Ononiwu, I.M., Osowole, O.S., Oduola, O.O., Ashidi, J.S., Oduola, A.M.J., 2003. Cultural categorization of febrile illness in correlation with herbal remedies use for treatment in Southwestern Nigeria. J. Ethnopharmacol. 85, 179186.

Amegnona, A.A., Eklu-Gadegbeku, E.G.K., Aklikokou, A.K, Koffi, M., 2003. The Effect of Mangifera indica stem bark and Pluchea ovalis on tracheal smooth muscle in vitro. Fitoterapia. 73, 619-622.

API, 2009. The Ayurvedic Pharmacopoeia of India. Government of India. Ministry of Health and Family Welfare .Department of Ayush . Part I, Vol.II: 25.

Boots, A.W., Haenen, G.R., Bast A., 2008. Health effects of quercetin: From antioxidant to nutraceutica. Eur. J. Pharmacol. 585, 325-337.

Calixto, J.B., Santos, A.R., Cechinel Filho, V., Yunes, R.A., 1998. A review of the plants of the genus Phyllanthus: Their chemistry, pharmacology, and therapeutic potential. Med. Res. Rev. 18(4), 225258.

Chah, K.F., Eze, C.A., Emuelosi, C.E., Esimone, C.O., 2006. Antibacterial and wound healing properties of mechanistic extracts of some Nigerian medicinal plants. J. Ethnopharmacol. 104, 164-167.

Chattopadhyay, R.R., 2003. Possible mechanism of hepatoprotective activity of Azadirachta indica leaf extract. Part II. J. Ethnopharmacol. 89, 217-219.

Chen, C. Y., Chang, Y. H., Bau, D. T., Huang, H. J., Tsai, F. J., Tsai, C. H., Chen, C. Y. C., 2009. Discovery of potent inhibitors for phosphodiesterase 5 by virtual screening and pharmacophore analysis. Acta Pharmacol. Sinica. 30(8), 1186-1194.

Erena, Y., Özatab, A., 2014. Determination of mutagenic and cytotoxic effects of Limonium globuliferum aqueous extracts by Allium, Ames, and MTT tests. Rev. Bras. Farmacognosia. 24, 51-59.

Ettarh, R.R., Emeka, P., 2004. Morinda lucida extract induces endothluim dependent and independent relation of rat aorta. Fitoterapia. 75, 332-336.

Gupta, S., Ganguli, S., Datta, D., Datta, A., 2013. Studies on interactions of histone proteins with mitomycin and chlordane provide insights into mechanisms of chemical clastogenesis. Natura J. 17.

Hashemi, M., Behrangi, N., Borna, H., Akbarzadeh, A., 2012. Evaluating new targets of natural anticancer molecules through bioinformatics tools. J. Proteomics Bioinform. 5, 50-53.

Leonard, E., Runguphan, W., O'Connor, S., Prather, K.J., 2009. Opportunities in metabolic engineering to facilitate scalable alkaloid production. Nat. Chem. Biol. 5, 292-300.

Nevalainen, T.J., 1975. Cytotoxicity of vinblastine and vincristine to pancreatic acinar cells. Virchows Archiv. B. 18(1), 119-127.

Obi, R.K., Iroagba II., Ojiako, O.A., 2006. Virucidal potential of some edible Nigerian vegetables. Afr. J. Biotechnol. 5(19), 1785-1788.

Phosrithong, N., Ungwitayatorn, J., 2010. Molecular docking study on anticancer activity of plant-derived natural products. Med. Chem. Res. 19(8), 817-835.

Rahman, L.U., Verma, P.C., Singh, D., Gupta, M.M., Banerjee, S., 2002. Bacoside production by suspension cultures of Bacopa monnieri (L.) Pennell. Biotechnol. Lett. 4(17), 1427-1429.

Rakuambo, N.C., Meyer, J.J.M., Hussein, A., Huyser, C., Moilalose, S.P., Raidani, T.G., 2006. In vitro effort of medicinal plants used to treat erectile dysfunction on smooth muscle relation and human sperm. J. Ethnopharmacol. 105, 84-88.

Sertel, S., Fu, Y., Zu, Y., Rebacz, B., Konkimalla, B., Plinkert, P.K., Krämer, A., Gertsch, J., Efferth, T., 2011. Molecular docking and pharmacogenomics of Vinca alkaloids and their monomeric precursors, vindoline and catharanthine. Biochem. Pharmacol. 81(6), 723-735.

Setzer, W.N., Ogungbe, I.V., 2012. In-silico investigation of antitrypanosomal phytochemicals from Nigerian medicinal plants. PLoS Negl. Trop. Dis. 6(7), 1727.

Shobana, C., Sumathi, T., Sujatha, L., Sureshkannan, S., Kumarasamy, P., 2013. Molecular docking studies of Bacoside-A, an active component of Bacopa monniera with DJ1 for Anti-Parkinson's drug design. Biomirror. 4, 67-70.

Snyder, R.D., Holt, P.A., Maguire, J.M., Trent, J.O., 2013. Prediction of noncovalent drug/DNA interaction using computational docking models: Studies with over 1350 launched drugs. Environ. Mol. Mutagen. 54(8), 668-681.

Snyder, R.D., McNultya, J., Zairova, G., Ewingb, D.E., Hendry, L.B., 2005. The influence of N-dialkyl and other cationic substituents on DNA intercalation and genotoxicity. Mutation Res. Fundament. Mol. Mechan. Mutagen. 578(1), 88-99.

Stone, A.A., Chambers, T.C., 2000. Microtubule inhibitors elicit differential effects on MAP kinase (JNK, ERK, and p38) signaling pathways in human KB-3 carcinoma cells. Exp. Cell Res. 254(1), 110119.

van Der Heijden, R., Jacobs, D.I., Snoeijer,W., Hallard, 
D., Verpoorte, R., 2004. The Catharanthus alkaloids: Pharmacognosy and biotechnology. Curr. Med. Chem. 11(5), 607-628.

Vandna, M., Nazneen, P., Singhal, K.C., Nizam, U.K., 2005. Antifilarial activity of Azadirachta indica on cattle filaria parasite, Setaria cervi. Fitoterapia. 76, 54-61.

Yuriev, E., Ramsland, P.A., 2013. Latest developments in molecular docking: 2010-2011 in review. J. Mol. Recogn. 26(5), 215-239.

\section{How to cite this article:}

Joardar, S., Ghosh, S., Gupta, S., Ganguli, S., 2017. In vitro and computational assessment of genotoxic potential of active constituents present in three medicinally important plant extracts. Int. J. Curr. Res. Biosci. Plant Biol. 4(7), 119-128. doi: https://doi.org/10.20546/ijcrbp.2017.407.015 